Rabaska

Revue d'ethnologie de l'Amérique française

\title{
Répertoire des chansons françaises de tradition orale
}

Volume 2, 2004

URI : https://id.erudit.org/iderudit/039391ar

DOI : https://doi.org/10.7202/039391ar

Aller au sommaire du numéro

Éditeur(s)

Société québécoise d'ethnologie

ISSN

1703-7433 (imprimé)

1916-7350 (numérique)

Découvrir la revue

Citer ce document

(2004). Répertoire des chansons françaises de tradition orale. Rabaska, 2,

159-159. https://doi.org/10.7202/039391ar d'utilisation que vous pouvez consulter en ligne.

https://apropos.erudit.org/fr/usagers/politique-dutilisation/ 


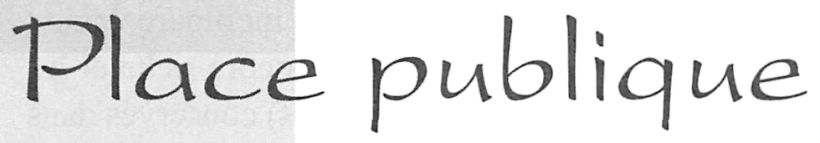

\title{
Points de vue
}

\section{Répertoire des chansons françaises de tradition orale}

À la veille de l'achèvement de la publication du Répertoire des chansons françaises de tradition orale de Patrice Coirault, dont les deux premiers tomes ont paru à Paris sous la direction de Georges Delarue en 1996 et en 2000, Rabaska a sollicité les avis de chercheurs qui ont déjà utilisé intensivement ce nouvel outil de recherche et qui connaissaient tout aussi bien les six volumes du Catalogue de la chanson folklorique française de Conrad Laforte, publiés à Québec entre 1977 et 1987. Des collègues français, Donatien Laurent, de Brest, et son compatriote Georges Delarue, de Grenoble, se joignent ainsi à notre confrère franco-ontarien Marcel Bénéteau, de Windsor, pour apprécier les qualités du Répertoire en regard des acquis du Catalogue.

Patrice Coirault, Répertoire des chansons françaises de tradition orale. Ouvrage révisé et complété par Georges Delarue, Yvette Fédoroff et Simone Wallon. Paris, Bibliothèque nationale de France, Tome I, La Poésie et l'amour, 1996, 566 p. ISBN 2-7177-1990-3 ; et Tome II, La vie sociale et militaire 2000, 635 p. ISBN 2-71772104-5.

\section{Comparaison des catalogues Coirault et Laforte}

\author{
DONATIEN LAURENT \\ Université de Bretagne occidentale, Brest \\ en collaboration avec
}

Georges Delarue

Centre alpin et rhodanien d'ethnologie, Grenoble

\section{Préliminaire}

On connaît l'incroyable richesse de la chanson française de tradition orale, tant du point de vue des textes que de la musique, et le rôle historique qu'elle a pu jouer dans la formation et l'évolution du répertoire chansonnier des différents peuples d'Europe. Il n'en est que plus surprenant qu'elle ait si peu retenu l'attention des milieux universitaires français au cours du dernier demi- 